research professor of the Royal Society, thereby being relieved of teaching duties. He began extensive investigations of the spectrum of molecular hydrogen with T. Tanaka, K. Das, P. M. Davidson, T. B. Rymer and others, and he himself made major contributions to the analysis of this most difficult of all molecular spectra. His book, "Molecular Hydrogen and its Spectrum", published in 1934, was based on his Silliman Memorial Lectures at Yale University. He retained interest in the $\mathrm{H}_{2}$ triplet fine structures, on which he had unpublished high-resolution data, almost up to the time of his death. His last paper appeared in 1953; he had retired from the Yarrow professorship in 1944. Other work at King's Colloge included an attempt, very early in the era of wave mechanics, to calculate the cold emission from metals under intense fields, and, in collaboration with $\mathrm{H}$. 'T. Flint, interesting speculation concerning a lesst proper time.

Soft X-ray spectra of several metals were studied, especially with the late F. C. and Mrs. Chalklin. Extensive investigations of the emission of electrons during chemical reactions were undertaken, first with the late L. G. Grimmett and later with A. K. Denisoff. He acquired a splendid reflexion echelon for measurement of the wave-numbers and structure of the Lyman $\alpha$ line of $\mathrm{H}$. He collaborated with W. E. Williams and J. Drinkwater in first measuring the wave-numbers and structures of the $H \alpha$ and $D \alpha$ lines to test the Dirac theory. Regrettably, a mysterious error crept into these observations. The results misled physicists until the Lamb-Retherford experiments. He made a notable study (1944) with the late Irena Gimpel of the reflexion of very slow electrons by copper, with apparatus earlier perfected by A. M. Crooker.

Richardson received honorary degrees of the University of Leeds (D.Sc.), St. Andrews and London (LL.D.); he was an honorary Fellow of King's College, London, and Trinity College, Cambridge. He was knighted in 1939 . He was president of the Physical Society during 1926-28 and its honorary foreign secretery during 1928-45, which capacity included entertaining many distinguished foreign visitors.

There will be many who will recall his generous hospitality, and his first wife, the sister of H. A. Wilson, who was a most gracious hostess. He had a beautiful home with the finest English period furniture and a dazzling collection of paintings by Dutch and other old masters, fit for any national collection. About the house were several grandfather clocks, one in his library, by a contemporary of Thomas Tompion. They were wound once a week by the local clockmaker.

Sir Owen was a quiet and kindly man of few. well-chosen words, but he had a keen sense of humour, $\mathrm{He}$ was exceedingly proud of his northern origins and could speak the Yorkshire dialect. His forebears of Dewsbury were manufacturers, in the trade of the district. One of his stories (generally true, with a good moral) concerned two of these individuals, engaged in the development of a machine for processing eloth. After much time and effort and failure in getting the machine to work, one remarked despondently to the other, "It wearnt go". After some thought, the other replied firmly, "It mun go !" The work proceeded. In due course the machine was perfected. It was called the Mungo machine.

Richardson was versed in botany and nearly took up this subject at Cambridge instead of physics. He kept a fine garden. About the outbreak of the Second World War he bought a large farm, some miles from his home at Alton, Hampshire, and supervised this for several years. He bought it as an investment, as a war effort, and, he said, to try and get back the fortune lost there by some of his ancestors who had migrated south to that part.

His two sons and a daughter and his second wife survive him. His elder son is professor of physics at Bedford College, London.

E. W. Foster

$$
\text { Dr. W. H. Mills, F.R.S. }
$$

The sudden death of William Hobson Mills on February 22, at the age of eighty-five, deprived Cambridge chemistry of its last link with the nineteenth century. Mills went up to Jesus College from Uppingham in 1892, and took first classes in both parts of the Natural Sciences Tripos. After his election to a research fellowship in 1899 , he went to Tübingen to work with von Pechmann, and there began his life-long friendship with N. V. Sidgwick. Upon his return to England he left Cambridge to become head of the Chemistry Department at the Northern Polytechnic in London, and during his ten years there he began the stereochemical work which was to gain for him an international reputation. $\mathrm{He}$ returned to Cambridge in 1912 as a Fellow of Jesus and demonstrator to the Jacksonian professor (then Sir James Dewar), and he remained there until his death.

Mills's achievements in the field of stereochemistry will always rank among the most powerful contributions made to the subject, for he had a flair for planning and carrying out a decisive experiment. By the synthesis and resolution into optically active forms of suitable compounds, he and his colleagues successfully demonstrated the non-linearity of carbon, nitrogen and oxygen in the oximes, the tetrahedral distribution of valencies in substituted ammonium ions and zinc complexes, and the planar configuration around 4-co-ordinated dipositive palladium and platinum. He played a great part in developing the steric theory to account for the optical activity of certain ortho-substituted diphenyls, and he later extended the idea of steric hindrance to free rotation to naphthalene, quinoline and benzene derivatives. Mills and Maitland, by their demonstration of optical activity in $1: 3$-diphenyl $1: 3$-di- $\alpha$-naphthylallene, confirmed a prediction made fifty years earlier by van't Hoff and, as a writer in the "Annual Reports on the Progress of Chemistry" put it, "realized one of the ambitions of all stereochemists". Mills also made important discoveries in connexion with the chemistry of cyanine dyes and alkyl-substituted pyridines and quinolines.

Mills was elected to the Royal Society in 1923, and he received the Davy Medal in 1935; he was appointed to a personal readership in stereochemistry at Cambridge in 1931, and he was George Fisher Baker Lecturer at Cornell in 1937. Unfortunately, he could never be persuaded to publish the lectures and, indeed, throughout his life he seldom published anything but self-contained original papers. He was president of the Chemical Society during 1941-44. After his retirement, he seldom visited the laboratory, but he retained a wide interest in scientific matters, and his 1942 Pedler Lecture on "The Basis of Stereochemistry" anticipated much that has since been written on that subject. 
No account of Mills's life would be complete without a reference to his extensive knowledge of the British flora and ornithology. He also had a long memory and a good knowledge of Cambridge history, and his excellence as a raconteur made him always entertaining company in the combination room of the College of which he was for nearly fifty years a Fellow, and during 1940-48 President. A. G. SHARPE

\section{The Rev. H. H. Symonds}

The Rev. H. H. Symonds died on December 28, after a long and painful illness; by his death, the Council for the Preservation of Rural England, the corresponding body in Wales and the rural preservation movement as a whole have sustained an irreparable loss. He was a firm believer in the value and possibilities of national parks for the good of the community, and made this province especially his own. $\mathrm{He}$ was largely responsible for the establishment in 1935 of the Standing Committee on National Parks of the Councils for the Preservation of Rural England and Wales under the chairmanship of Mr. Norman (now Lord) Birkett. This became his absorbing interest and together with the late John Dower he took on the work of honorary drafting secretary which he carried out until 1952, when he asked to be relieved of the duties so as to enable him to devote his time to other urgent work in connexion with the North Wales (Hydro-Electricity) Protection Committee, of which he was chairman. To his labours in the field of national parks to rouse and sustain public interest may justly be ascribed the introduction of the National Parks Act and the establishment of the National Parks Commission. It was a great disappointment to him that his tenure of office as a National Parks commissioner-an appointment long overdue when it at last came-was ended so quickly and abruptly by the illness which caused his death.
Symonds was no sentimentalist. $\mathrm{He}$ was a very able, hard-hitting protagonist, respected by his critics and opponents and admired by his friends and supporters. He was possessed of ability and intellect of the highest order; he had the gift of making the obscure transparent and the difficult plain. We must esteem him for his unswerving fidelity to his principles and his fearless propagation of his views. It would have been a great reproach to Britain if national parks did not exist as an enduring and appropriate memorial to one who was so entirely devoted to their service. HERBERT GRIFFIN

\section{Mr. Augustine Courtauld}

Mr. Augustine Courtauld, son of Samuel Courtauld, of Courtaulds, Ltd., died after a long illness on March 3. From his Cambridge days he hed been interested in exploration and had travelled in Greenland with J. M. Wordie, of St. John's College, now Sir James Wordie, and in the Sahara with Francis Rodd, later Lord Rennell of Rodd. During 1930-31 he was in Greenland as a member of Watkins's British Arctic Air Route Expedition, and during the winter manned alone the meteorological station near the centre of the ice cap. The difficulties of travel on the ice cap in the autumn had made it impossible to stock the station with sufficient food and fuel for two men, and Courtauld, at his own request, stayed there alone-a feat of personal heroism and endurance, quietly undertaken, which equals any in polar exploration.

Courtauld was not a scientist; his interests were literary, but he equipped himself as a surveyor to make himself useful on expeditions. He shared the leadership of a successful expedition in 1935 to the Watkins Mountains of East Greenland. The party climbed the highest mountain in the Arctic, since named by the Danes, Gunnbjørns Fjæld, 3,700 m.

\section{NEWS and VIEWS}

\section{Department of Scientific and Industrial Research} Wolfe Award: Dr. L. Essen, O.B.E.

Dr. L. Essen was recently presented by Lord Hailsham, Lord President of the Council, with the Wolfe Award of the Department of Scientific and Industrial Research, in the form of a cheque for $£ 500$. This is the first of ten annual Awards to be made, under the terms of a will, to the scientist who has made an outstanding contribution to the research work of the Department during the previous twelve months.

Dr. Essen, a senior principal scientific officer at the National Physical Laboratory, received the Award for his work on the establishment of an atomic frequency standard as a basis for the future standard of time. Although the first attempts to employ molecular and atomic frequencies as 'clocks' were made in the United States, Dr. Essen was the first to appreciate the vital importance of this earlier work as a possible basis for a new physical standard of time. The cæsium frequency standard that he designed is used to calibrate the quartz clocks at the National Physical Laboratory and to monitor the $M . S . F$. standard frequency transmissions. Valuable information has been obtained on the performance of quartz clocks, the propagation of radio signals, the periodic and irregular variations of the rate of rotation of the Earth, and the value of the present international standard of time in terms of a particular frequency of the cæsium atom. The unit of time provided by the present atomic frequency standard can be determined in a few minutes to an accuracy of 2 parts in 10,000 million. This figure of merit is ten times better than that recently announced from measurements, extending over three years, of the astronomical unit based on the period of the Earth's revolution around the Sun. The National Physical Laboratory standard has, in effect, been the time standard of the world for the past three years.

\section{Iron and Steel Institute: Medals and Prizes}

The Council of the Iron and Steel Institute has awarded the following medals and prizes: Bessemer Gold Medal for 1959 to Prof. Bo Kalling, until recently director of research, Stora Kopparbergs Bergslags Aktiebolag, Sweden; Sir Robert Hadfield Medal for 1959 to Mr. Albert Jackson, technical adviser on steelmaking to the United Steel Companies, Ltd. ; Andrew Carnegie Silver Medal for 1958 to Dr. P. Vasudevan, Department of Metallurgy, University of Manchester, 